\title{
The effect of spinal and general anesthesia on metastatic lymph node flow in bladder cancer surgery: A pilot study
}

\author{
Mesane kanseri cerrahisinde spinal ve genel anestezinin metastatik lenf nodu akımı üzerine \\ etkisi: Pilot çalışma
}

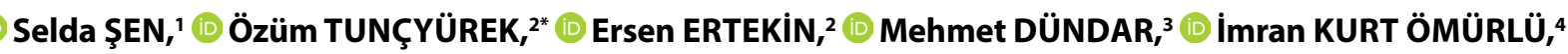 \\ Sinem SARI ${ }^{1}$
}

\section{Summary}

Objectives: The sympathetic regulation of contractile function of lymphatic vessels has received much attention in terms of metastasis mechanism nowadays in animal studies. The aim of the study was to evaluate the effect of spinal or general anesthesia on flow in malignant lymph nodes in patients undergoing bladder tumor surgery with Doppler ultrasound.

Methods: This prospective, observational, pilot study was performed on the patients (American Society of Anesthesiologists II and III, aged 45-85) who scheduled for elective bladder tumor surgery under spinal or general anesthesia from July 2018 to August 2019. Patients were divided into two groups, spinal anesthesia and general anesthesia. Resistivity index, pulsatility index (PI), peak systolic velocity, and end-diastolic velocity measurements were recorded preoperatively and postoperatively in the inguinal lymph nodes by Doppler ultrasound.

Results: In the malignant lymph nodes, the PI value decreased with the spinal anesthesia $(n=12)$ compared to the pre-operative period ( $p=0.002)$ but increased in the general anesthesia group $(n=11)(p=0.003)$. There was a significant difference in post-operative PI between the two groups ( $p=0.0001$ ) (cutoff $\geq 5.49$, sensitivity $81.82 \%$, and specificity $91.67 \%$ ). Post-operative peak systolic velocity values were significantly higher than pre-operative values only in general anesthesia group $(p=0.021)$.

Conclusion: Lymphatic flow in metastatic lymph nodes decreased by spinal anesthesia compared to general anesthesia evaluated using Doppler ultrasound in our study. Although this new mechanism is new in the reduction of lymphatic metastasis during cancer surgery, prospective randomized studies evaluating long-term recurrence and survival are warranted.

Keywords: Bladder cancer; Doppler ultrasound; lymph nodes; metastasis; spinal anesthesia.

\section{Öz}

Amaç: Lenfatik damarların kasılma fonksiyonunun sempatik regülasyonu, günümüzde hayvan çalışmalarında metastaz mekanizması açısından çok dikkat çekmektedir. Bu çalışmanın amacı, mesane tümör cerrahisi geçiren hastalarda spinal veya genel anestezinin malign lenf nodlarındaki akım üzerine etkisini doppler ultrason ile değerlendirmektir.

Gereç ve Yöntem: Bu prospektif, gözlemsel, pilot çalışma, Temmuz 2018'den Ağustos 2019'a kadar spinal veya genel anestezi altında elektif mesane tümör cerrahisi planlanan hastalarda (ASA II ve III, 45-85 yaşlarında) yapıldı. Hastalar iki gruba ayrılarak, spinal ve genel anestezi. uygulamasından önce ve sonra Doppler ultrason ile inguinal lenf nodlarında rezistivite indeksi, pulsatilite indeksi, pik sistolik hız ve end diyastolik hız ölçümleri kaydedildi.

Bulgular: Malign lenf nodlarında pulsatilite indeks değeri spinal anestezi $(n=12)$ ile ameliyat öncesi döneme $(p=0.002)$ göre azaldı, ancak genel anestezi grubunda $(n=11)$ arttı $(p=0.003)$. İki grup arasında postoperatif pulsatilite indeksinde anlamlı bir fark vardı ( $p=0.0001$ ) (cut off 5.49, duyarlıık \%81.82, özgüllük \%91.67). Postoperatif pik sistolik hız değerleri sadece genel anestezi grubunda preoperatif değerlerden anlamlı derecede yüksekti $(p=0.021)$.

Sonuç: Çalışmamızda doppler ultrasonografi ile değerlendirilen metastatik lenf nodlarındaki lenfatik akım spinal anestezi uygulamasında genel anesteziye göre azalmaktadır. Her ne kadar bu mekanizma kanser cerrahisi sırasında lenfatik metastazın azaltılmasında yeni olsa da, bu konuda uzun süreli nüks ve sağkalımı değerlendiren prospektif randomize çalışmalar gereklidir.

Anahtar sözcükler: mesane kanseri; Doppler ultrasonografi; lenf nodları; metastaz; spinal anestezi.

*The current affiliation of the author: Department of Radiology, Near East University Faculty of Medicine, Nicosia, Turkish Republic of Northern Cyprus

'Department of Anesthesiology and Reanimation, Adnan Menderes University Faculty of Medicine, Aydın, Turkey

${ }^{2}$ Department of Radiology, Adnan Menderes University Faculty of Medicine, Aydın, Turkey

${ }^{3}$ Department of Urology, Adnan Menderes University Faculty of Medicine, Aydın, Turkey

${ }^{4}$ Department of Biostatical, Adnan Menderes University Faculty of Medicine, Aydın, Turkey

Submitted (Başvuru tarihi) 02.06.2020 Accepted after revision (Düzeltme sonrası kabul tarihi) 02.09.2020 Available online date (Online yayımlanma tarihi) 11.01.2021

Correspondence: Dr. Selda Şen. Adnan Menderes Üniversitesi Tıp Fakültesi, Anesteziyoloji ve Reanimasyon Anabilim Dalı, Aydın, Turkey.

Phone: +90 - 356 - $4441256 / 2101$ e-mail: drseldasen@yahoo.com

(C) 2021 Turkish Society of Algology 


\section{Introduction}

Cancer incidence and related mortality are rapidly growing worldwide and resulting in 9.6 million deaths in 2018, and the bladder cancer is the $10^{\text {th }}$ most common form of cancer worldwide with 200,000 deaths. ${ }^{[1]}$ Surgery is a mainstay of treatment for many malignant tumors; but, surgical manipulation leads to a significant systemic release of tumor cells. ${ }^{[2]}$

Different anesthesia techniques (regional, general, or together) suggested playing a role in the development of metastases after cancer surgery. ${ }^{[3]}$ Multiple factors such as stress response to surgery, relative immune suppression, inflammatory factors, possible direct effects of volatile anesthetics, opioids, and other medications during the perioperative period influence tumor cell survival. ${ }^{[4]}$ Although some retrospective studies have shown that regional anesthesia reduces operative stress response in different cancer surgeries, evidence of the utility of regional anesthesia techniques in tumor recurrence has been found to be inconclusive. ${ }^{[5]}$ Despite this assessment, the recent urological literature suggests that there may be a relationship between anesthetic type and outcome for bladder and prostate cancer surgery. ${ }^{[6,7]}$ Metastasis to the lymph nodes plays an important role in determining prognosis in bladder tumors. ${ }^{[8]}$ Koumpan et al. ${ }^{[7]}$ found in their retrospective study that patients who received spinal anesthesia had a lower incidence of recurrence and a delayed time to recurrence following transurethral bladder tumor resection for nonmuscle invasive bladder cancer.

The regulation of contractile function of lymphatic vessel by the autonomic nervous system has received considerable attention in cancer prognosis. ${ }^{[9]}$ Although, the effect of sympathetic system on the flow in lymph vessels and nodes has been demonstrated in animal experiments and isolated organ studies, there are no objective data on human clinical studies. ${ }^{[9,10]}$ Therefore, we tested the primary hypothesis that the flow in the malignant lymph nodes decreases with sympathetic block during spinal anesthesia when compared to general anesthesia in transurethral resection of bladder tumor surgery determined by Doppler ultrasonography.

\section{Material and Methods}

This prospective, observational study was conducted in patients with transurethral resection of bladder tumor surgery under spinal or general anesthesia by the approval of the ethical committee (2018/1430) and written informed consent of patients. Spinal or general anesthesia was given to patients with aged between 30 and 80 years who according to the American Society of Anesthesiologists Class II or III physical status.

Before the procedure, all patients received intravenous midazolam $0.02 \mathrm{mg} / \mathrm{kg}$ for premedication. Spinal anesthesia was performed from the $L$ 2-3 or L 3-4 interspinous space in the sitting position with 26 Quincke needle (Atraucan; B. Braun, Melsungen, Germany) and $0.5 \%$ hyperbaric bupivacaine $12.5 \mathrm{mg}$ was given. Patients in general anesthesia group were given intravenous propofol $2-3 \mathrm{mg} / \mathrm{kg}$, fentanyl 1 $\mathrm{mcg} / \mathrm{kg}$, and rocuronium $0.6 \mathrm{mg} / \mathrm{kg}$ for anesthesia induction and were intubated. Maintenance of anesthesia was provided with $0.25-0.5 \mathrm{mcg} / \mathrm{kg} / \mathrm{min}$ remifentanil infusion, $2 \%$ sevoflurane, and $50 \%$ air/ oxygen mixture and fresh gas flow at $3 \mathrm{~L} / \mathrm{min}$. The heart rate $(\mathrm{HR})$, non-invasive arterial blood pressure, and peripheral oxygen saturation $\left(\mathrm{SpO}_{2}\right)$ were monitored in all patients at pre-operative, peroperative, and post-operative periods. Hypotension was defined as either systolic blood pressure $<100 \mathrm{mmHg}$ or a reduction of $>20 \%$ from baseline. Symptomatic hypotension treated with small intravenous doses of ephedrine (e.g., 5-10 mg) and intravenous fluids. Hemodynamic parameters and ephedrine requirement were recorded in all patients. Color Doppler ultrasound (General Electric Company Healthcare LOGIQ e Ultrasound Machine, Connecticut, USA) was used by the radiologist for measuring the superficial inguinal lymph nodes flow at preoperative and $1^{\text {st }} \mathrm{h}$ of spinal anesthesia. If multiple lymph nodes were detected in one inguinal region, the largest lymph node was included in the study. To make the diagnosis of malignant lymph node, we examined the morphological structure of the superficial inguinal lymph node (size larger than $1 \mathrm{~cm}$, round shape, heterogeneous structure) and the vascular resistance [resistive index (RI) and pulsatility index (PI) over 0.8 and 1.6, respectively] parameters by spectral Doppler ultrasound as defined in the literature. ${ }^{[11]}$ We also examined the peak systolic velocity and end- 


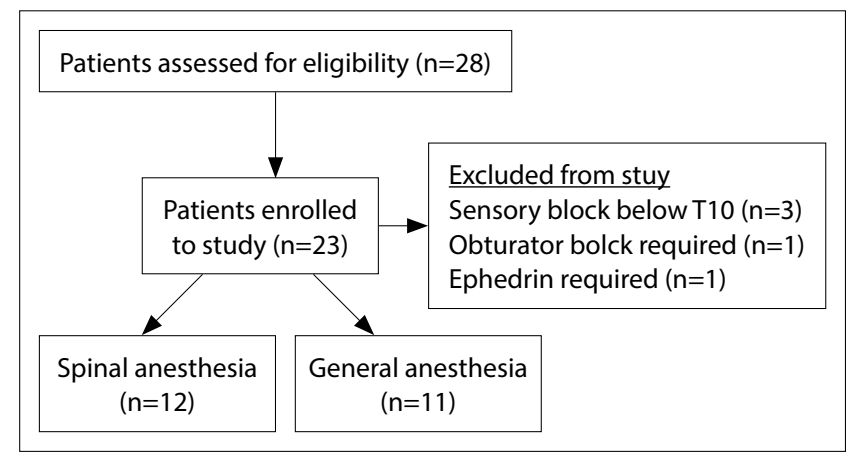

Figure 1. Flow diagram of the study.

diastolic velocity which are used to calculate the PI by ultrasound in the lymph node.

Patients were excluded to study in the following cases; patients without post-operative measurement, sensory block under T10, or patients with obturator nerve block requirement (to prevent adduction of the thigh during transurethral bladder surgery), or patients who previously received beta-blockers, or patients required ephedrine for hypotension.

The Kolmogorov-Smirnov test was used to assess the normality of numeric variables. For the numeric variables that were normally distributed, comparison between two groups was made by independent sample $\mathrm{t}$-test and descriptive statistics are presented as mean \pm standard deviation. For the numeric variables that were not normally distributed, comparison between two groups was made by Mann-Whitney U- or Wilcoxon t-tests and descriptive statistics are presented as median (25-75 percentiles). ROC analysis was used to evaluate the predictive performance of PI.

\section{Results}

This study was performed on 28 patients with transurethral resection of bladder tumor surgery under spinal or general anesthesia. The reasons for exclusion of five out of 28 patients were as follows: Spinal anesthesia sensory block level was below T10 in three patients, obturator nerve block was required in one patient for operation, and $30 \mathrm{mg}$ ephedrine due to hypotension in one patient. Twenty-three patients were divided into two groups as spinal $(n=12)$ and general anesthesia $(n=11)$ (Fig. 1). Pre-operative ultrasound examination revealed malignant and benign lymph nodes in all patients (Fig. 2). Pathological evaluations supported the malignancy of the lymph nodes detected by ultrasound. In the post-operative period, $\mathrm{PI}$ value decreased in spinal anesthesia group compared to pre-operative period $(p=0.002)$ and increased in general anesthesia group $(p=0.003)$. There was a significant difference between the two groups in terms of post-operative PI value $(p=0.0001)$ (Fig. 3) (cutoff $\geq 5.49$, sensitivity $81.82 \%$, and specificity 91.67\%). Post-operative PI values were significantly higher in the general anesthesia group compared to the pre-operative values $(p=0.021)$. In the benign lymph nodes, no significant difference was found in ultrasound measurements as spinal and general anesthesia (Table 1).

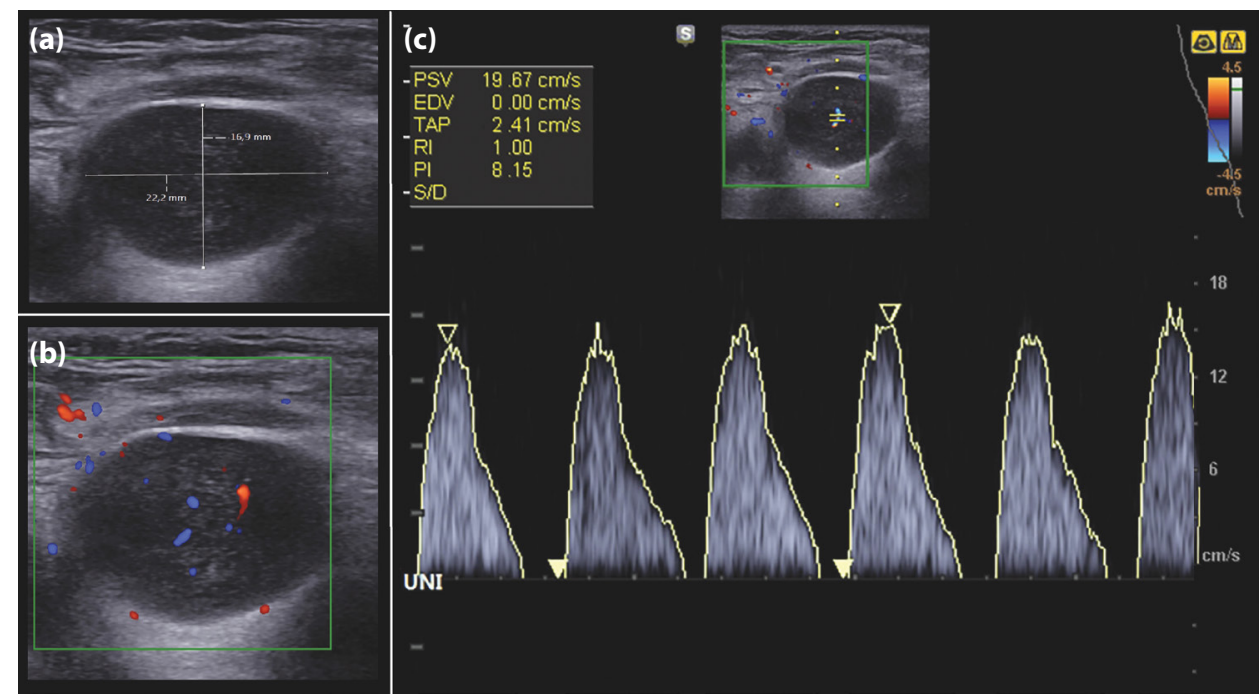

Figure 2. Doppler ultrasound findings in malign lymph node. (a) Metastatic nodes tend to be round with increased short axis-to-long axis ratio ( $\mathrm{S} / \mathrm{L}$ ratio). (b) Malign nodal vascular pattern: Mixed peripheral and central increased vascularization. (c) Color Doppler flow imaging with quantitative parameters of vascularity such as increased pulsatility index (PI) and arterial resistive index (RI) in malign lymph nodes. 


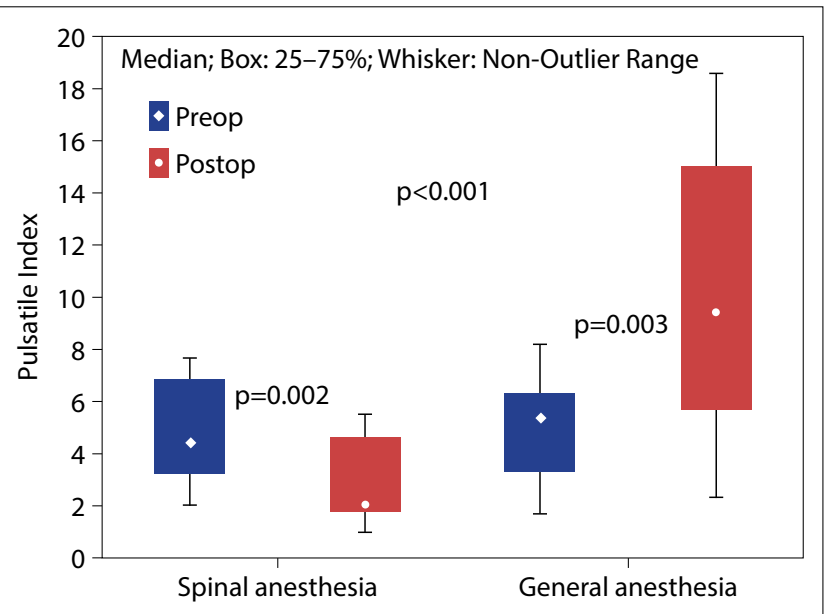

Figure 3. Pulsatility index (PI) values of malignant lymph nodes after spinal and general anesthesia. Mann-Whitney U-test for statistics between groups, related samples Wilcoxon for ingroup statistics. PI values between the two groups $(p<0.001)$ (cutoff $=>5.49$, sensitivity $81.82 \%$, and specificity $91.67 \%$ ).

\section{Discussion}

Consistent with the literature, pre-operative resistivity index and PI levels were high in malignant lymph nodes and low in benign lymph nodes when evaluated by the color Doppler ultrasound. We determined that $\mathrm{PI}$ values decreased in the malignant lymph nodes postoperatively with spinal anesthesia and increased with general anesthesia. To the best of our knowledge, this is the first study showing this difference between spinal versus general anesthesia. Furthermore, in benign lymph nodes, no significant difference was found after spinal or general anesthesia.

Lymph node involvement in bladder cancer occurs in approximately $30 \%$ of cases invading the bladder wall (stage T2), unfortunately, the presence of nodal involvement is associated with a significant reduction in 5-year disease-free survival. ${ }^{[12,13]} \mathrm{N} 1$ disease is defined as bladder cancer involvement of one regional pelvic lymph node and these regional lymph nodes are inguinal, hypogastric (internal iliac chain), obturator, external iliac chain, perivesical, presacral, and the common iliac artery lymph nodes. ${ }^{[12,14]} \mathrm{Al}-$ though surgical procedures are performed usually without lymph metastasis like in most of our bladder tumor cases, late diagnosis is common which represents with lymph node metastasis.

On ultrasound examination, rounding of lymph nodes, irregular borders, the absence of a fatty hilum, clustering of several lymph nodes, and peripheral vessel localization with chaotic intranodal
Table 1. Demographic data and Doppler ultrasound values of patients

\begin{tabular}{|c|c|c|}
\hline & $\begin{array}{c}\text { Spinal } \\
\text { anesthesia }\end{array}$ & $\begin{array}{c}\text { General } \\
\text { anesthesia }\end{array}$ \\
\hline Age (mean $\pm S D)$ & $66.58 \pm 11.02$ & $66.72 \pm 7.26$ \\
\hline $\begin{array}{l}\text { Body mass index } \\
(\text { mean } \pm S D)\end{array}$ & $27.23 \pm 2.42$ & $26.81 \pm 3.79$ \\
\hline \multicolumn{3}{|l|}{$\mathrm{RI}$} \\
\hline Preop benign & $0.6(0.55-1)$ & $0.7(0.6-1)$ \\
\hline Postop & $0.6(0.4-1)$ & $1(0.7-1)$ \\
\hline \multicolumn{3}{|l|}{$\mathrm{RI}$} \\
\hline Preop malign & $1(1-1)$ & $1(1-1)$ \\
\hline Postop & $1(1-1)$ & $1(1-1.4)$ \\
\hline \multicolumn{3}{|l|}{ PSV } \\
\hline Preop malign & $7.60(5.83-10.46)$ & $5.96(4.67-8.71)$ \\
\hline Postop* & $6.74(5.32-10.66)$ & $8.70(6.90-12.7)$ \\
\hline \multicolumn{3}{|l|}{ PSV } \\
\hline Preop benign & 4.70 (6.91-9.54) & $4.92(4.67-9.74)$ \\
\hline Postop & $4.42(4.62-9.71)$ & $5.41(5.7-9.3)$ \\
\hline \multicolumn{3}{|l|}{ EDV } \\
\hline Preop malign & $0(0-2.7)$ & $0(0-0)$ \\
\hline Postop & $0(0-0)$ & $0(0-0)$ \\
\hline \multicolumn{3}{|l|}{ EDV } \\
\hline Preop bening & $0(0-0.16)$ & $0(0-0.27)$ \\
\hline Postop & $0(0-0.1)$ & $0(0-0.14)$ \\
\hline \multicolumn{3}{|l|}{$\mathrm{PI}$} \\
\hline Preop bening & $1.24(0.43-2.16)$ & $1.05(0.51-1.7)$ \\
\hline Postop & $1.14(0.3-1.9)$ & $1.26(0.6-1.94)$ \\
\hline
\end{tabular}

*: $P=0.021$ Postoperative PSV values were significantly higher than preoperative values only in general anesthesia group. RI: Resistivity index; PI: Pulsatility index; PSV: Peak systolic velocity; EDV: End diastolic velocity; Preop: Preoperative; Postop: Postoperative Resistivity Index = PSV-EDV /PSV and Pulsatility Index = PSV- EDV /AT. ${ }^{[20]}$

vascular branching may indicate malignancy. Color Doppler ultrasound can be used to distinguish malignant or benign by looking at vascular structure in lymph nodes. The ( $\mathrm{PI}>1.6)$ and arterial $(\mathrm{RI}>0.8)$ measured in the vascular structure are useful parameters for the evaluation of malignancy in color Doppler flow imaging of the lymph node. ${ }^{[11,15]}$ In the spectral waveform analysis, high resistivity and Pls values as an indicator of increased peripheral vascular resistance for malignant lymph nodes are reported. ${ }^{[1]]}$ It was recently found that color Doppler ultrasound diagnosis for the reactive lymph nodes with a sensitivity of $92 \%$ and specificity of $97.3 \% .{ }^{[16]}$ Morphological features and vascularity parameters (high RI and PI values) of malignant lymph nodes in our study were 
consistent with the literature (Fig. 2). Whereas, in benign lymph nodes, resistivity index and PI values were below the threshold values.

Although the functions of the sympathetic nervous system in the lymphatic vessels have been known since the early 2000s, the sympathetic regulation of contractile function of lymphatic vessels has received much attention nowadays for the prevention of metastasis in cancer patients. ${ }^{[10]}$ Similarly, Childers et al. ${ }^{[17]}$ found that the use of $\beta$-blockers significantly reduced risk of breast cancer recurrence and breast cancer death in their meta-analysis. On the other hand, Hiller et al. ${ }^{[18]}$ reported that spinal anesthesia reduces lymphatic flow (in lymphatic vessels and nodes) through a likely mechanism of sympathectomy in patients with cervical and prostate cancer for brachytherapy. In their studies, accumulation of radioisotope-labeled colloid was decreased in inguinal lymph nodes and lymphatic vessels after spinal anesthesia. They reported that sympathetic block (at T9-L1 chain) with spinal anesthesia can decrease lymphatic flow, while operative stress and general anesthesia increase sympathetic stimulation. Similarly, we observed that PI values in malignant lymph nodes were decreased in spinal anesthesia group and increased in general anesthesia group compared to pre-operative values. In our study, decrease in blood pressure and HR in patients with spinal anesthesia can be considered as an indicator of sympathetic blockade. Sensory block reaching T10 level with spinal anesthesia may provide appropriate analgesia and sympathetic block for transurethral resection of bladder tumor surgery operations. ${ }^{[19]}$

Bachmann et al. ${ }^{[10]}$ also found that tumor-draining lymphatic vessels exhibited more active contractility and that this contraction activity can be inhibited by distinct agonists and antagonists of the autonomic nervous system in murine model. In malignant lymph nodes, when tumor cells compress the vascular structures in the lymph tissue or abnormal vascular structure occurs, there is an increase in vascular resistance (shown with pulsatile index) compared to benign lymph nodes. ${ }^{[1]]}$ Since the sympathetic system has more effect on malignant lymph nodes in murine model, ${ }^{[10]}$ we thought that sympathetic block with spinal anesthesia may cause more decrease in vascular resistance (pulsatile index) than general an- esthesia in human. In our study, we have not detected significant differences for PI and RI values in benign lymph nodes before and after spinal anesthesia in contrast to malignant lymph nodes. This may be because benign lymph nodes are less affected by sympathetic activity.

There are number of limitations of our study. Although the numbers of patients included are limited, still the difference between spinal and general anesthesia groups was found to be quite high for PI values. The distinction between malignant and benign lymph nodes was made only by Doppler ultrasound. Malignancy was not differentiated by computed tomography or magnetic resonance imaging. Long-term prognoses of the patients were not collected which limits clinical correlation of our results. Since our aim was to evaluate the lymphatic flow in the early period of the operation, the measurements were taken only in the pre-operative period and 1 $\mathrm{h}$ after spinal anesthesia (maximum effect of spinal anesthesia). No other measurement was made except the pre-operative period and $60^{\text {th }}$ min of spinal anesthesia. Limiting how long the effect lasts on the lymph nodes.

\section{Conclusions}

Lymphatic flow in metastatic lymph nodes decreased by spinal anesthesia compared to general anesthesia evaluated using color Doppler ultrasound. With the spinal anesthesia, the release of tumor cells from the surgical site and metastatic lymph nodes can be reduced, which may benefit for survival. Although this new mechanism is new in the reduction of lymphatic metastasis during cancer surgery, prospective randomized studies evaluating long-term recurrence and survival are warranted.

Acknowledgments: We thank Alparslan Turan, MD (Cleveland Clinic), for invaluable help in the preparation of the final manuscript.

Ethics Committee Approval: This prospective, observational study was conducted in patients with transurethral resection of bladder tumor surgery under spinal or general anesthesia by the approval of the ethical committee (2018/1430).

Conflict-of-interest issues regarding the authorship or article: None declared.

Peer-rewiew: Externally peer-reviewed. 


\section{References}

1. Bray F, Ferlay J, Soerjomataram I, Siegel RL, Torre LA, Jemal A. Global cancer statistics 2018: GLOBOCAN estimates of incidence and mortality worldwide for 36 cancers in 185 countries. CA Cancer J Clin 2018;68(6):394-424. [CrossRef]

2. Tohme S, Simmons RL, Tsung A. Surgery for cancer: A trigger for metastases. Cancer Res 2017;77(7):1548-52. [CrossRef]

3. Yang W, Cai J, Zabkiewicz C, Zhang H, Ruge F, Jiang WG. The effects of anesthetics on recurrence and metastasis of cancer, and clinical implications. World J Oncol 2017;8(3):6370. [CrossRef]

4. Wall T, Sherwin A, Ma D, Buggy DJ. Influence of perioperative anaesthetic and analgesic interventions on oncological outcomes: A narrative review. $\mathrm{Br} J$ Anaesth 2019;123(2):135-50. [CrossRef]

5. Cakmakkaya OS, Kolodzie K, Apfel CC, Pace NL. Anaesthetic techniques for risk of malignant tumour recurrence. Cochrane Database Syst Rev 2014;11:CD008877. [CrossRef]

6. Lusty AJ, Hosier GW, Koti M, Chenard S, Mizubuti GB, Jaeger $M$, et al. Anesthetic technique and oncological outcomes in urology: A clinical practice review. Urol Oncol 2019;37(12):845-52. [CrossRef]

7. Koumpan $Y$, Jaeger $M$, Mizubuti GB, Tanzola R, Jain $K$, Hosier $\mathrm{G}$, et al. Spinal anesthesia is associated with lower recurrence rates after resection of nonmuscle invasive bladder cancer. J Urol 2018;199(4):940-6. [CrossRef]

8. Aldousari $\mathrm{S}$, Kassouf W. Update on the management of non-muscle invasive bladder cancer. Can Urol Assoc J 2010;4(1):56-64. [CrossRef]

9. Scallan JP, Zawieja SD, Castorena-Gonzalez JA, Davis MJ. Lymphatic pumping: Mechanics, mechanisms and malfunction. J Physiol 2016;594(20):5749-68. [CrossRef]

10. Bachmann S, Gsponer D, Montoya-Zegarra JA, Schneider $\mathrm{M}$, Scholkmann F, Tacconi $C$, et al. A distinct role of the autonomic nervous system in modulating the function of lymphatic vessels under physiological and tumor-draining conditions. Cell Rep 2019;27(11):3305-14.e13. [CrossRef]
11. Mao $Y$, Hedgire $S$, Harisinghan M. Radiologic assessment of lymph nodes in oncologic patients. Curr Radiol Rep 2014;2:36. [CrossRef]

12. Shankar PR, Barkmeier D, Hadjiiski L, Cohan RH. A pictorial review of bladder cancer nodal metastases. Transl Androl Urol 2018;7(5):804-13. [CrossRef]

13. Horn T, Zahel T, Adt N, Schmid SC, Heck MM, Thalgott MK, et al. Evaluation of computed tomography for lymph node staging in bladder cancer prior to radical cystectomy. Urol Int 2016;96(1):51-6. [CrossRef]

14. Paner GP, Stadler WM, Hansel DE, Montironi R, Lin DW, Amin MB. Updates in the eighth edition of the tumornode-metastasis staging classification for urologic cancers. Eur Urol 2018;73(4):560-9. [CrossRef]

15. Ahuja AT, Ying M, Ho SY, Antonio G, Lee YP, King AD, et al. Ultrasound of malignant cervical lymph nodes. Cancer Imaging 2008;8(1):48-56. [CrossRef]

16. Pattanayak S, Chatterjee S, Ravikumar R, Nijhawan VS, Sharma V, Debnath J. Ultrasound evaluation of cervical lymphadenopathy: Can it reduce the need of histopathology/ cytopathology? Med J Armed Forces India 2018;74(3):22734. [CrossRef]

17. Childers WK, Hollenbeak CS, Cheriyath P. $\beta$-blockers reduce breast cancer recurrence and breast cancer death: A metaanalysis. Clin Breast Cancer 2015;15(6):426-31. [CrossRef]

18. Hiller JG, Ismail HM, Hofman MS, Narayan K, Ramdave S, Riedel BJ. Neuraxial anesthesia reduces lymphatic flow: Proof-of-concept in first in-human study. Anesth Analg 2016;123(5):1325-7. [CrossRef]

19. Gupta S, Sampley S, Kathuria S, Katyal S. Intrathecal sufentanil or fentanyl as adjuvants to low dose bupivacaine in endoscopic urological procedures. J Anaesthesiol Clin Pharmacol 2013;29(4):509-15. [CrossRef]

20. Steinkemp HJ, Maurer J, Cornebl M. Recurrent cervical lymphadenopathy: Differential diagnosis with color-duplex sonography. Eur Arch Otorhinolaryngol 1994;251:404-9. [CrossRef] 